\title{
The English Speech of Francophone Primary School Teachers and Cours Moyen Deux (CM2) Pupils in Cameroon
}

\author{
Jean-Paul Kouega ${ }^{1}$, Emmanuel Ombouda Onana ${ }^{2}$ \\ ${ }^{1}$ Department of English, University of Yaounde I, Yaounde, Cameroon \\ ${ }^{2}$ Language Unit, Management Sciences and Business School, Catholic University of Douala, Douala, Cameroon
}

Email address:

jkouega@yahoo.co.uk (Jean-Paul K.)

\section{To cite this article:}

Jean-Paul Kouega, Emmanuel Ombouda Onana. The English Speech of Francophone Primary School Teachers and Cours Moyen Deux (CM2) Pupils in Cameroon. International Journal of Language and Linguistics. Vol. 6, No. 3, 2018, pp. 90-100.

doi: $10.11648 /$ j.ij11.20180603.15

Received: May 5, 2018; Accepted: May 28, 2018; Published: June 19, 2018

\begin{abstract}
This paper examines the English spoken productions of primary school teachers and their graduating pupils in Cameroon, with the aim of checking how much English is learnt by the time the primary child moves to the secondary education level. The data came from classroom observations, tape-recording of lessons as they were taught and a spoken performance test taken by the pupils. The work is couched within the structural approach to phonology, and the error analysis and the contrastive methods of analysis were used to describe the data. A number of interesting findings were obtained. First, francophone primary school teachers in Cameroon are not proficient in English and they cannot therefore teach the subject even though they were summoned to do it. Second, many francophone primary school pupils learn very little English and, as a result, secondary school teachers have no choice but to start the English subject from scratch. Characteristically, these pupils' spoken productions exhibit various features at the level of consonants like substitution, cluster simplification and realisation of silent letters. At the vocalic level, spelling pronunciation causes monophthongs to be replaced by foreign sounds, and diphthongs and triphthongs to be monophthongised. Most interestingly, vowel nasalization is systematic in specific contexts.
\end{abstract}

Keywords: Cameroon, Consonant, Francophone English, Learner English, Vowel

\section{Introduction}

Since Reunification in 1961, Cameroon has been implementing an official policy of French-English bilingualism and, close to 60 years today, the vast majority of Francophone Cameroonians cannot still function in Basic English. In an attempt to boost the learning of English by Francophone and French by Anglophone Cameroonians, Government decided that the second official language of each citizen should be taught as early as the first day of primary school. The purpose of this study, which focuses on English in primary school, is to check how much English is learnt at the phonological level by the time a Cameroonian child leaves primary school. The following four questions are set to guide the research exercise: What are the characteristic phonological features of the English of primary school teachers? What are the characteristic phonological features of the English of primary school leavers? From the features observed, can it be said that primary school leavers in Cameroon meet Government's expectations? Can it be said that Government is serious about its official French-English bilingualism policy? The work comprises three main sections entitled background to the study, methodology, and data analysis. These are considered in turn.

\section{Background to the Study}

For many years, successive governments in Cameroon have taken various measures to ensure the spread of official bilingualism in the country. The measures which are relevant to the present study have been taken as from the year 1996 . These measures, which are couched in the form of orders, decrees, ordinances, service notes and circular letters, are listed below: 
- an order stipulating that every primary school teacher would henceforth teach every subject on the school syllabus including the second official language subject was issued (Order No 21/E/59 of May 15, 1996 organising the Grade One teacher certificate examination);

- a primary school syllabus outlining how each subject including the second official language subject would be taught was designed by the Ministry of Education (MINEDUC [1], Kouega [2])

- an order introducing the second official language subject in both the written and oral parts of the First School Leaving Certificate (FSLC) examinations and its French equivalent, the Certificat d'Etudes Primaires (CEP) examinations was issued (Order No 66/C/13 of February 16, 2001);

- a circular letter instructing primary and nursery education state officials to see that bilingualism is effective in all nursery and primary schools (circular letter No 033/B1/1464/MINEDUC/IE/ IGPBIL of October 14, 2002) was issued;

- a circular letter instructing teacher training college principals to provide adequate training so that student-teachers be sufficiently equipped to teach the second official language
(Circular letter No 009/B1/1464/MINEDUC/IGE/IGP/BIL of April 9, 2003) was issued.

It was envisaged that, after these decisions and measures are implemented fully, every Cameroonian citizen would be bilingual in French and English and every pupil who leaves primary education would have learned enough French and English to be capable of following courses taught in either official language at the secondary education level. With this target in mind, education officials set the general objectives of the teaching of English in Class Six as follows:

- to provide the learners with English that they will use at the end of their primary school education in their daily life requirements;

- to establish a basis for further work in English for those who will go into secondary education;

- to expose learners to other aspects of the English speaking culture

- to foster bilingualism and national integration.

To attain these objectives, Government officials decided that the communicative teaching method was to be applied and relevant structural features were to be taught, as Table 1 (MINEDUC [1], p. 32) shows:

Table 1. The CM2 English syllabus.

\begin{tabular}{ll}
\hline Communicative objectives & Structural focus \\
\hline Talking about one's present actions & We are cleaning the room. \\
& We sweep the classroom everyday. \\
Talking about one's habitual actions & She comes to school on Friday \\
& They go home every weekend... \\
Describing what one is good at & She is good at mathematics/jumping... \\
Describing the activities of someone & He is a good fisherman. He catches fish with a net \\
Talking about one's future intentions & She is going to visit her aunt next week. I shall visit my uncle next year... \\
Comparing people and things & He is taller than I. Peter is more intelligent that John. An elephant is stronger than a cow. This bamboo is a \\
Talking about hypothetical situations & long as that ruler... \\
Expressing one's wishes & If I have headache, I will take some tablets. If it rains tomorrow, I'll take my umbrella. \\
Talking about the past & I would like to be a teacher, I wish I were a bird... \\
Counting objects & I was in class four when I was eight years old... \\
Describing a journey & Counting up to 1,000,000 (one million) \\
Predicting outcomes & The journey was interesting / boring / dangerous. \\
Describing ways of travelling & Following this story/situation, I think... \\
\hline
\end{tabular}

The contents of the prescribed textbook (Champions in English CM2, published by EDICEF) that was to be used to attain these objectives is reproduced in Table 2 .

Table 2. Contents of Champions in English CM2 (Class Six).

\begin{tabular}{lll}
\hline Units in the book & Pages & Grammar points tackled \\
\hline Unit 1 & $5-8$ & Can for ability and inability, Revision of Present continuous Negative forms \\
Unit 2 & $9-12$ & Simple present, Revision of Present continuous, be good at + . ing Adjectives, Simple past: regular and irregular verbs \\
Unit 3 & $13-16$ & Why? Because..., Simple present for habitual action, Going to + infinitive, Imperatives \\
Revision pages: & Grammar exercises 20, Vocabulary exercises 21 \\
Unit 4 & $23-26$ & Correct reactions, Revision of Simple past, Going to + infinitive \\
Unit 5 & $27-30$ & Going to + infinitive, Comparatives: as ... as/... er than Likes and dislikes \\
Unit 6 & $31-34$ & Description: There is/are; You can see... + preposition Adverbs of frequency: always, never sometime to have the right to \\
Revision pages: Grammar exercises 37, Vocabulary exercises 38 \\
Unit 7 & $41-44$ & Simple present \\
Unit 8 & $45-48$ & Simple past: regular and irregular verbs \\
Unit 9 & $49-52$ & Simple present, Simple past, Imperatives, Giving reasons \\
Revision pages: Grammar exercises 54, Vocabulary exercises 55 \\
Unit 10 & $59-62$ & Giving reasons, Asking questions, Present continuous Adjectives \\
Unit 11 & $63-66$ & Asking questions, Simple past, enough + noun Simple present \\
\hline
\end{tabular}




\begin{tabular}{lll}
\hline Units in the book & Pages & Grammar points tackled \\
\hline Unit 12 & $67-70$ & Giving reasons, Present continuous Simple past \\
Revision page: Grammar exercises 71, Vocabulary exercises 72 \\
Wordlist 73-78
\end{tabular}

Various evaluations of these measures have been made. Some evaluations were made by Government officials themselves (e.g. MINEDUC [3]). Other evaluations were made by a number of researchers, among others: Constable [4], Tchoungui [5], Kouega [6, 2, 7, 8, 9], Biloa [10], Echu [11], Simo Bobda [12], Ombouda Onana [13], Sokeng Piewo [14], and Kouega and Sokeng Piewo [15]. Their findings revealed that the official bilingualism policy fails to produce bilingual Cameroonians. At all stages of language acquisition, this policy, which is still in practice in the country today, is a sheer waste of resources. At the primary level of education, pupils are expected to be provided with "English that they will use ... in their daily life requirements" (MINEDUC [1] p. 30). Unfortunately, most of the teachers have not been taught English let alone being taught how to teach English (Abang [16]). As a result, when primary school leavers move on to secondary education, they are re-taught the basics of English as they had learnt nothing worth building on. The purpose of the present study is to check how much English is learnt at the phonological level by the time a Cameroonian child leaves primary school.

\section{Methodology}

A total of 112 informants of both sexes (pupils, and CM2 teachers) took part in this study. These were: 60 Cours Moyen 2 pupils henceforth CM2 pupils (i.e. primary Class 6 pupils) aged 9-12, 40 Sixième pupils (Form One) aged 10-14, and $12 C M 2$ teachers. The 60 CM2 pupils came from six schools selected at random in the following residential areas in the city of Yaounde: Bastos, Ekoudou, Messa, Sources, Tsinga, and Tsinga Olinga. In each of the selected schools, two CM2 classes were chosen i.e. 12 classes in all. The teachers of these 12 classes were also chosen and they turned out to be 7 female and 5 male. Then, in each of the six schools, ten pupils were randomly selected, with the focus on the pupils' gender i.e. 30 female and 30 male. The 40 Form One pupils, aged 10-14, came from Government secondary schools located in the following residential areas: Cité Verte,
Nkol-Bisson, Nkol-Eton, and Tsinga. In each of the schools visited, ten pupils i.e. five female and five male, were selected at random.

The data came from tape-recorded lectures and a reading test. In each school, one teacher's lecture was tape-recorded. As for the pupils, they were made to read some passages drawn from their textbook, which was "Champions in English" at that time. The passages chosen contained targeted words. For example, the passage entitled "A CELEBRATION!” (p. 28) was chosen because it contains words like "birth, women, children, etc." In order to complete the data, additional words were selected from other passages of this same book and were read by the informants. From these two sets of spoken data, some 369 phonological errors were identified.

\section{Analysis}

The analysis is limited to segmental features. The symbols that are used to represent RP segments are those used in the 2016 edition of the CALD - Cambridge Advanced Learner's Dictionary (2016), which combines the written transcriptions of words with their on-line oral renditions. Consonants are considered first and vowels next.

\subsection{Consonants}

The segments $/ \mathrm{v} /, / \theta, \mathrm{\delta} /, / \mathrm{z} /, / 3 /, / \mathrm{h} /, / \mathrm{t} \int, \mathrm{d} 3 /$ and $/ \mathrm{r} /$ on the one hand and RP consonant clusters on the other are taken up in turn. Consonant segments are considered first. The segments $/ \mathrm{v} /, / \theta, \mathrm{\partial} /, / \mathrm{z} /, / 3 /, / \mathrm{h} /, / \mathrm{t} \int, \mathrm{d} 3 /$ and $/ \mathrm{r} /$ pose a very serious problem to pupils and their teachers. The labio-dental fricative $/ \mathrm{v} /$ which is a sound produced with the lower lip touching the upper teeth, is usually pronounced accurately when it is represented by the letter V as in "visit". When represented by other letters like F in "of" and PH in "nephew", it is pronounced as spelt, as shown in Table 3 where "FrancoE" stands for "Francophone English".

Table 3. Renditions of the labio-dental fricative $/ v /$.

\begin{tabular}{|c|c|c|c|c|c|}
\hline Informants & RP segment & FrancoE equivalent & Words & RP rendering & FrancoE rendering \\
\hline Class Six teachers & $/ \mathrm{v} /$ & /f/ & of; nephew & /pv/;/'nevju:/ & /f/; /ne'fy/; N=12 (100\%) \\
\hline Class Six pupils & $/ \mathrm{v} /$ & /f/ & of; nephew & /nv/; /'nevju/ & /Df/; /ne'fy/; N=60 (100\%) \\
\hline Form One pupils & $/ \mathrm{v} /$ & $/ \mathrm{f} /$ & of; nephew & /pv/;/'nevju:/ & /Df/; /ne'fy/; N=40 (100\%) \\
\hline
\end{tabular}

Table 3 shows that all the teachers and their pupils mispronounced the words "of" and "nephew", surely because the letters $\mathrm{F}$ and $\mathrm{PH}$ are systematically rendered as /f/ in French, as the words "foi" (faith) and "phare" (headlight of a car) illustrate.
Interdental sounds, which are represented by the letter sequence $\mathrm{TH}$, are produced with the tip of the tongue inserted between the upper and lower teeth. The voiceless $/ \theta /$ is replaced by the alveolar $/ \mathrm{t} /$ as in Table 4 and its voiced counterpart is replaced by $/ \mathrm{d} /$ as shown in Table 5 . 
Table 4. Renditions of the voiceless interdental fricative $/ \theta /$.

\begin{tabular}{|c|c|c|c|c|c|c|}
\hline Teachers and pupils & RP segment & FrancoE equivalent & Examples & RP rendering & Franc & \\
\hline Class Six teachers & $/ \theta /$ & 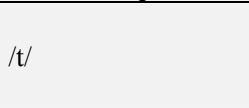 & $\begin{array}{l}\text { think } \\
\text { healthy } \\
\text { teeth }\end{array}$ & 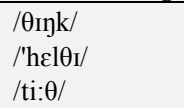 & $\begin{array}{l}/ \text { tin/ } \\
/ \text { /'clti/ } \\
/ \text { tit/ }\end{array}$ & $\mathrm{N}=12(100 \%)$ \\
\hline Class Six pupils & $/ \theta /$ & $/ \mathrm{t} /$ & $\begin{array}{l}\text { think } \\
\text { three } \\
\text { healthy }\end{array}$ & 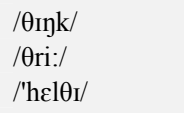 & $\begin{array}{l}/ \text { tip/ } \\
/ \text { ta'si/ } \\
\text { /elti/ }\end{array}$ & $\mathrm{N}=60(100 \%)$ \\
\hline Form One pupils & $/ \theta /$ & $/ \mathrm{t} /$ & $\begin{array}{l}\text { think } \\
\text { three } \\
\text { healthy }\end{array}$ & $\begin{array}{l}\text { / } \theta \mathrm{rnk} / \\
/ \theta \mathrm{ri}: / \\
/ \text { 'hel } \theta \mathrm{r} /\end{array}$ & $\begin{array}{l}/ \text { tin/ } \\
/ \text { ta'si/ } \\
/ \varepsilon 1 \text { lit/ }\end{array}$ & $\mathrm{N}=40(100 \%)$ \\
\hline
\end{tabular}

Table 5. Renditions of the voiced interdental fricative/ $/ /$.

\begin{tabular}{|c|c|c|c|c|c|c|}
\hline Teachers and pupils & RP segment & FrancoE equivalent & Examples & RP rendering & \multicolumn{2}{|c|}{ FrancoE rendering } \\
\hline Class Six teachers & /ð/ & $/ \mathrm{d} /$ & $\begin{array}{l}\text { there } \\
\text { brother } \\
\text { with }\end{array}$ & $\begin{array}{l}\text { /ðєә/ } \\
\text { /"brıðа/ } \\
\text { /wıð/ }\end{array}$ & $\begin{array}{l}\text { /dєь/ } \\
\text { /'bьоdєь/ } \\
\text { /wid/ }\end{array}$ & $\mathrm{N}=12(100 \%)$ \\
\hline Class Six pupils & /ठ/ & $/ \mathrm{d} /$ & $\begin{array}{l}\text { the } \\
\text { father } \\
\text { with }\end{array}$ & $\begin{array}{l}\text { /ठа/ } \\
\text { /'fa:ðə/ } \\
\text { /wıð/ }\end{array}$ & $\begin{array}{l}\text { /də/ } \\
\text { /'fadeь/ } \\
\text { /wid/ }\end{array}$ & $\mathrm{N}=60(100 \%)$ \\
\hline Form One pupils & /ð/ & $/ \mathrm{d} /$ & $\begin{array}{l}\text { the } \\
\text { father } \\
\text { with }\end{array}$ & $\begin{array}{l}\text { /ðә/ } \\
\text { /'fa:ðә/ } \\
\text { /wı// }\end{array}$ & $\begin{array}{l}\text { /də/ } \\
\text { /'fades/ } \\
\text { /wid/ }\end{array}$ & $\mathrm{N}=40(100 \%)$ \\
\hline
\end{tabular}

The replacement of interdentals with alveolar sounds is systematic in Cameroon as it is also observed in Cameroon English (Simo Bobda [17], Kouega [18]).

The alveolar fricative $/ z /$ is a sound produced with the tip of the tongue touching the alveolar. This sound is usually pronounced accurately when it is represented by the letter Z as in "zoo", but when it is represented by the letter S or SS as in "husband, "possessive", "dessert", it is devoiced as shown in Table 6.

Table 6. Renditions of the alveolar fricative $/ z /$.

\begin{tabular}{|c|c|c|c|c|c|}
\hline Teachers and pupils & RP segment & FrancoE equivalent & Examples & RP rendering & FrancoE rendering \\
\hline Class Six teachers & $\mid \mathrm{z} /$ & $/ \mathrm{s} /$ & Husband; possessive & /'hızbənd/; /pə'zesıv/ & /ysbã/; /pose'siv/; N=12 (100\%) \\
\hline Class Six pupils & $|z|$ & $/ \mathrm{s} /$ & dessert; possessive & /dı'zз:t/; /pa'zesıv/ & /de'sєь/; /pose'siv/; N=60 (100\%) \\
\hline Form One pupils & $|z|$ & $/ \mathrm{s} /$ & dessert; possessive & /dı'zз:t/; /pə'zesıv/ & /de'sєь/; /pose'siv/; N=40 (100\%) \\
\hline
\end{tabular}

This rendering is influenced by French, a language in which the digraph SS is pronounced /s/ as in assemblée (assemby) and the letter $\mathrm{S}$ is pronounced $/ \mathrm{z} /$ when it occurs between vowel letters as in poser (to put).

The palato-alveolar fricative $/ 3 /$ is a sound realised with the front of the tongue touching the front part of the hard palate. This sound can be represented by the letter sequences SU as in "usually, pleasure", SI as in "vision", TI as in "equation" etc. It is usually replaced by the alveolars /z/ and /s/ (Table 7).

Table 7. Renditions of the palato-alveolar fricative /3/.

\begin{tabular}{|c|c|c|c|c|c|}
\hline Teachers and pupils & RP segment & FrancoE equivalent & Examples & RP rendering & FrancoE rendering \\
\hline Class Six teachers & /3/ & $|z|$ & usually & /'ju:3əlı / & /'yzuali/; N=12 (100\%) \\
\hline Class Six pupils & $13 /$ & $\mid \mathrm{z} / ; / \mathrm{s} /$ & vision; equation & /'vi3n/; /I'kwer3n/ & /vi'zjō/; /ekwa'sj̃̃/; N=60 (100\%) \\
\hline Form One pupils & $13 /$ & $\mid \mathrm{z} / ; / \mathrm{s} /$ & vision; equation & /'vi3n/; /I'kwer3n/ & /vi'zjō/; /ekwa'sj̃̄/; N=40 (100\%) \\
\hline
\end{tabular}

The glottal fricative $/ \mathrm{h} /$ is a sound produced when the vocal cords are pulled apart, the glottis allowing the air from the lungs to move out freely without any articulator modifying its course. This sound, which is represented by the letter $\mathrm{H}$ as in "hospital" and "happy", is systematically omitted by all the informants, as Table 8 shows.

Table 8. Renditions of the glottal fricative $/ \mathrm{h} /$.

\begin{tabular}{|c|c|c|c|c|c|}
\hline Teachers and pupils & RP segment & FrancoE equivalent & Examples & $R P$ rendering & FrancoE rendering \\
\hline Class Six teachers & $/ \mathrm{h} /$ & $1 /$ & hello; homework & /hələu/; /'həomwək/ & /elo/;/'omwDk/; N=12 (100\%) \\
\hline Class Six pupils & $/ \mathrm{h} /$ & 11 & hello; hospital & /hə'ləə)/; /'hospitl// & /'elo/; /ospi'tal/; N=60 (100\%) \\
\hline Form One pupils & $/ \mathrm{h} /$ & 11 & hello; hospital & /hə'ləo/; /'hpsprtl/ & /'elo/; /ospi'tal/; N=40 (100\%) \\
\hline
\end{tabular}

The palatal affricates $/ \mathrm{t} \mathrm{f} /$ and $/ \mathrm{d} 3 /$ are sounds produced with the front of the tongue placed in the middle of the hard palate. These sounds usually pose a serious problem to the informants. The voiceless $/ \mathrm{t} / /$ is generally represented by the letter sequence $\mathrm{CH}$ as in "choose" and the voiced /d3/ by the letters $\mathrm{J}$ as in "enjoy" and $\mathrm{G}$ as in "large". They are systematically replaced by the palato-alveolar segments / $/ \mathrm{f} / \mathrm{and} / 3 /$, as shown in Table 9 . 
Table 9. Renditions of the palatal affricates /t $\mathrm{f} \%$

\begin{tabular}{|c|c|c|c|c|c|}
\hline Teachers and pupils & RP segment & FrancoE equivalent & Examples & RP rendering & FrancoE rendering \\
\hline Class Six teachers & $/ \mathrm{t} / /$ & $/ \mathrm{d} /$ & choose; touch & /tfu:z/; /thtf/ & $/$ / oz/; /tJS/; N=12 (100\%) \\
\hline Class Six pupils & $/ \mathrm{t} /$ & $/ 2 /$ & check; touch & $/ \mathrm{t} \int \mathrm{\varepsilon k} / ; / \mathrm{t} \Lambda \mathrm{t} \int /$ & $/ \int \mathrm{gk} / ; / \mathrm{tuJ} / ; \mathrm{N}=60(100 \%)$ \\
\hline Form One pupils & $\mid \mathrm{t} /$ & /g/ & check; touch & $/ \mathrm{t} \int \varepsilon \mathrm{\varepsilon k} / ; / \mathrm{t} \Lambda \mathrm{t} \int /$ & $/ \mathrm{sk} / ; / \mathrm{tuJ} / ; \mathrm{N}=40(100 \%)$ \\
\hline
\end{tabular}

This is obviously due to the fact that $\mathrm{CH}$ is rendered as $/ \mathrm{J} /$ in French, as in the word échanger (to change). Similarly, the letters $\mathrm{G}$ and $\mathrm{J}$ (Table 10) are rendered $/ 3 /$ as in large (large) and juste (just).

Table 10. Renditions of the palatal affricates /d3/.

\begin{tabular}{|c|c|c|c|c|c|}
\hline Teachers and pupils & RP segment & FrancoE equivalent & Examples & $\mathrm{RP}$ rendering & FrancoE rendering \\
\hline Class Six teachers & $/ \mathrm{d} 3 /$ & $/ 3 /$ & enjoy & $/$ /n'd3:Ji/ & /'๕̃зวi/; N=12 (100\%) \\
\hline Class Six pupils & $/ \mathrm{d} 3 /$ & $/ 3 /$ & just; large & /d3Ast///la:d3/ & /3yst/; /ав3/; N=60 (100\%) \\
\hline Form One pupils & $/ \mathrm{d} 3 /$ & $13 /$ & just; large & /d3Ast/;/la:d3/ & /3yst/; /ав3/; N=40 (100\%) \\
\hline
\end{tabular}

Lastly, the segment $/ \mathrm{r} /$ which is realised with the tip of the tongue producing a series of vibrating taps against the alveolar ridge, is represented by the letter $\mathrm{R}$ as in "red". This sound is replaced in all contexts by the French uvular fricative / $\mathrm{B} /$, as shown in Table 11.

Table 11. Renditions of the alveolar roll $/ \mathrm{r} /$.

\begin{tabular}{|c|c|c|c|c|c|}
\hline Teachers and pupils & RP segment & FrancoE equivalent & Examples & $\mathrm{RP}$ rendering & FrancoE rendering \\
\hline Class Six teachers & $/ \mathrm{r} /$ & $/ \mathrm{B} /$ & red; arrive & /rعd/; /ə'raIv/ & /вعd/; /а'ьір/; N=12 (100\%) \\
\hline Class Six pupils & $/ \mathrm{r} /$ & $/ \mathrm{B} /$ & red; arrive & /red/; /ə'raIv/ & /в $8 \mathrm{~d} / ;$ /а'ьір/; N=60 (100\%) \\
\hline Form One pupils & $/ \mathrm{r} /$ & $/ \mathrm{B} /$ & red; arrive & /red/; /ə'raIv/ & /вعd/; /а'ьір/; N=40 (100\%) \\
\hline
\end{tabular}

Some innovative renderings are observed. The French palatal nasal sound /n/ represented by the graphemes GN as in pagne (loincloth) is heard in all contexts where these graphemes occur, as in the word "recognize" (Table 12).

Table 12. Some innovative renderings: the foreign consonant $/ \mathrm{n} /$.

\begin{tabular}{|c|c|c|c|c|c|c|}
\hline Teachers and pupils & Grapheme & RP & FrancoE equivalent & Examples & RP rendering & FrancoE rendering \\
\hline Class Six teachers & GN & $/ \mathrm{gn} /$ & $/ \mathrm{n} /$ & recognise & /'rckəgnaiz/ & /вعk’'jniz/; N=12 (100\%) \\
\hline Class Six pupils & GN & /gn/ & $/ \mathrm{n} /$ & recognise & /'rekəgnaiz/ & /вعk''jiz/; N=60 (100\%) \\
\hline Form One pupils & GN & /gn/ & $/ \mathrm{n} /$ & recognise & /'rckəgnaiz/ & /вєk’'jiz/; N=40 (100\%) \\
\hline
\end{tabular}

Similarly, the silent letter $\mathrm{K}$ which is usually followed by $\mathrm{N}$ as in the words "knife", "know" is always articulated (Table 13). As the cluster $/ \mathrm{kn} /$ does not exist in French, this CC cluster is rendered as CVC by these learners. In other words, the sequence of letters $\mathrm{KN}$ is first transformed into $/ \mathrm{k} /+/ \mathrm{n} /$ and then realised as $/ \mathrm{k} /+/ \mathrm{on} /$ as shown in Table 13.

Table 13. Some innovative renderings: $/ n /$ rendered as $/ k a n /$.

\begin{tabular}{|c|c|c|c|c|c|c|}
\hline Teachers and pupils & Grapheme & RP segment & FrancoE equivalent & Examples & $\mathrm{RP}$ rendering & FrancoErendering \\
\hline Class Six teachers & $\mathrm{K}+\mathrm{N}$ & $/ \mathrm{n} /$ & /kən/ & knife know & /narf/; /nəひ/ & /kə'naif/; /kə'no/; N=12 (100\%) \\
\hline Class Six pupils & $\mathrm{K}+\mathrm{N}$ & $/ \mathrm{n} /$ & /kən/ & knife know & /narf/; /nəo/ & /kə'naif/; /kə'no/; N=60 (100\%) \\
\hline Form One pupils & $\mathrm{K}+\mathrm{N}$ & $/ \mathrm{n} /$ & /kən/ & knife know & /naIf/; /nəv/ & /kə'naif/; /kə'no/; N=40 (100\%) \\
\hline
\end{tabular}

RP consonant clusters are simplified by vowel epenthesis. Clusters ending in $/ 1 /$ and preceded by a consonant letter, i.e., $\mathrm{C}+/ \mathrm{l} /$ clusters like /bl/ as in "table", /dl/ as in "candle", /gl/ as in "single", /kl/ as "uncle", /pl/ as in "people", /tl/ as in "cattle" are all rendered as $\mathrm{C}+/ \mathrm{l} /+/ \mathrm{a} /$ or $\mathrm{CCV}$; hence the cluster /bl/ as in "table", "dribble", "able" becomes /blə/, as shown in Table 14.

Table 14. Rendering of $\mathrm{C}+/ \mathrm{l} / \mathrm{clusters} \mathrm{like} / \mathrm{bl} /$.

\begin{tabular}{|c|c|c|c|c|c|}
\hline Teachers and pupils & RP segment & FrancoE equivalent & Examples & RP rendering & FrancoE rendering \\
\hline Class Six teachers & $/ \mathrm{bl} /$ & /blə/ & table; dribble & /'terbl/; /'dribl/ & /'teblə/; /dкiblə/; N=12 (100\%) \\
\hline Class Six pupils & $/ \mathrm{bl} /$ & /bla/ & able; dribble & /'erbl/; /'drrbl/ & /ablə/; /'dsiblə/; N=60 (100\%) \\
\hline Form One pupils & $/ \mathrm{bl} /$ & /bla/ & able; dribble & /'erbl/; /'dribl/ & /'ablə/; /'dsiblə/; N=40 (100\%) \\
\hline
\end{tabular}

With the cluster /sm/ as in "bilingualism", "tribalism", the vowel / $\varepsilon /$ is inserted in-between the consonants, yielding a CVC structure, as in Table 15.

Table 15. Renderings of clusters ending in $/ \mathrm{m} /$.

\begin{tabular}{|c|c|c|c|c|c|}
\hline Teachers and pupils & RP segment & FrancoE equivalent & Examples & RP rendering & FrancoE rendering \\
\hline Class Six teachers & $\mathrm{zm} /$ & $/ \mathrm{zcm} /$ & bilingualism & /bai'lingwəlızm/ & /bilẽgwa'lizEm/; N=12 (100\%) \\
\hline Class Six pupils & $/ \mathrm{zm} /$ & /zem/ & tribalism & /'traibəlızm/ & /tuiba'lizem/; N=60 (100\%) \\
\hline Form One pupils & $/ \mathrm{zm} /$ & /zem/ & tribalism & /'trarbəlızm/ & /tuiba'lizem/; N=40 (100\%) \\
\hline
\end{tabular}


In clusters whose orthography contains a vowel letter like A in "total”, E in “clapped", “open”, “even”, "cooked”, and U in "wonderful", this vowel letter is articulated fully, as Table 16 shows.

Table 16. Renderings of clusters ending /t/.

\begin{tabular}{|c|c|c|c|c|c|}
\hline Teachers and pupils & RP segment & FrancoE equivalent & Examples & RP rendering & FrancoE rendering \\
\hline Class Six teachers & $/ \mathrm{pt} /$ & /pet/ & clapped & /klæpt/ & /'klapet/; N=12 (100\%) \\
\hline Class Six pupils & /kt/ & /ket/ & cooked & /kokt/ & /'kPOket/; N=60 (100\%) \\
\hline Form One pupils & $/ \mathrm{kt} /$ & /ket/ & cooked & /kokt/ & /'kPOket/; N=40 (100\%) \\
\hline
\end{tabular}

Silent letters are generally articulated, like B in the word "comb", GH in the word "daughter", L in the word "chalk", and $\mathrm{N}$ in the word "condemn". The grapheme GH in the word "daughter" is rendered with the velar $/ \mathrm{g} /$; this may derive from the pronunciation of French loans like "Ghana" and "ghetto". Table 17 brings together the three categories of informants i.e. Class Six teachers $(\mathrm{N}=12)$, Class Six pupils $(\mathrm{N}=60)$ and Form One pupils $(\mathrm{N}=40)$ under the single label Teachers and pupils $(\mathrm{N}=112)$. This is due to the observation that their renderings of words do not seem to differ in any way. When these three categories are brought together, the size of subsequent tables will be reduced considerably.

Table 17. Articulation of silent letters.

\begin{tabular}{|c|c|c|c|c|c|c|c|}
\hline & Graphemes & RP segment & FrancoE equivalent & Examples & RP rendering & FrancoE $\mathbf{r}$ & dering \\
\hline Teachers and pupils & $\mathrm{B}, \mathrm{L}, \mathrm{M}, \mathrm{GH}$ & // & $/ \mathrm{b} /, / 1 /, / \mathrm{m} /, / \mathrm{g} /$ & $\begin{array}{l}\text { comb } \\
\text { daughter } \\
\text { chalk } \\
\text { condemn }\end{array}$ & $\begin{array}{l}\text { /kəum/ } \\
\text { /dO:tə/ } \\
\text { /ţP:k } \\
\text { /kəndem/ }\end{array}$ & $\begin{array}{l}\text { /kOmb/ } \\
\text { /'dOgteь/ } \\
\text { /§Olk/ } \\
\text { /kõdEmn/ }\end{array}$ & $\mathrm{N}=112(100 \%)$ \\
\hline
\end{tabular}

In summary, the consonant system of the English of the informants of this study includes the sounds outlined in Table 18.

Table 18. The consonant system of the English of francophone learners.

\begin{tabular}{|c|c|c|}
\hline Consonants & Examples & Transcriptions \\
\hline$/ \mathrm{p} /$ & pan & pan \\
\hline$/ \mathrm{b} /$ & tube & tyb \\
\hline$/ \mathrm{t} /$ & cat & kat \\
\hline$/ \mathrm{d} /$ & $\underline{\text { do }}$ & $\mathrm{du}$ \\
\hline$/ \mathrm{k} /$ & book & buk \\
\hline /g/ & bag & bag \\
\hline /f/ & for & คв \\
\hline$/ \mathrm{s} /$ & dessert & deseb \\
\hline $\mid \mathrm{z} /$ & zoo & zOO \\
\hline $\mid \mathrm{S} /$ & which & wif \\
\hline /3/ & genius & 3enius \\
\hline /1/ & lot & $1 \mathrm{Dt}$ \\
\hline$/ \mathrm{m} /$ & moon & mつつn \\
\hline$/ \mathrm{n} /$ & $\operatorname{man}$ & $\operatorname{man}$ \\
\hline /j/ & yellow & jelo \\
\hline$/ \mathrm{w} /$ & $\underline{\text { well }}$ & wel \\
\hline
\end{tabular}

\subsection{Vowels}

Table 19. Renderings of the high front unrounded vowel $/ i$ :/

\begin{tabular}{|c|c|c|c|c|c|c|}
\hline & RP segment & FrancoE equivalent & Examples & RP rendering & FrancoE : & ering \\
\hline Teachers and pupils & /i:/ & $\begin{array}{l}/ \mathrm{e} \mathrm{O} / \\
/ \varepsilon / \\
/ \mathrm{i} \varepsilon /\end{array}$ & $\begin{array}{l}\text { people } \\
\text { receive } \\
\text { believe }\end{array}$ & $\begin{array}{l}\text { /'pi:pl/ } \\
\text { /ri'si:v/ } \\
\text { /br'li:v/ }\end{array}$ & $\begin{array}{l}\text { /pe'Oplə/ } \\
\text { /вe'scvə/ } \\
\text { /be'licvə/ }\end{array}$ & $\mathrm{N}=112(100 \%)$ \\
\hline
\end{tabular}

RP monophthongs, dipthongs, triphthongs, and lastly V+N (vowel + nasal sound) sequences are considered in turn. Monopthongs are considered first. The high front unrounded vowel /i:/ tends to be replaced by a variety of foreign monophthongs and diphthongs which seem to reflect the spelling of the words in which they occur, as Table 19 shows.

The same can be said of the high front unrounded vowel /I/, which is rendered by all the informants as /a/ in a word like "image", /o, $\varepsilon /$ in the two occurrences of this sound in the word "women", /y/ as in "busy" and /ui/ as in "biscuit". These renderings are presented in Table 20. 
Table 20. Renderings of the high front unrounded vowel /I/.

\begin{tabular}{|c|c|c|c|c|c|c|}
\hline & RP segment & FrancoE equivalent & Examples & RP rendering & FrancoE & ering \\
\hline \multirow{4}{*}{ Teachers and pupils } & \multirow{4}{*}{$/ \mathrm{I} /$} & $/ \mathrm{a} /$ & image & /'Imid3/ & /i'ma3/ & \multirow{4}{*}{$\mathrm{N}=112(100 \%)$} \\
\hline & & $/ o, \varepsilon /$ & women & /'wimin/ & /'women/ & \\
\hline & & $/ \mathrm{y} /$ & busy & /'bizi/ & /'byzi/ & \\
\hline & & /чi / & biscuit & /'biskit/ & /bis'kuit/ & \\
\hline
\end{tabular}

The mid-low vowel / $\varepsilon /$ does occur in the English of these informants, especially in words like "ten" and "pen" where the vowel is represented by the letter E. When this vowel is represented by a sequence of vowel letters as in "leopard", spelling pronunciation is applied, as shown in Table 21.

Table 21. Renderings of the vowel /ع/.

\begin{tabular}{|c|c|c|c|c|c|}
\hline & RP segment & FrancoE equivalent & Examples & $\mathrm{RP}$ rendering & FrancoE rendering \\
\hline Teachers and pupils & $\mid \varepsilon /$ & $\begin{array}{l}\text { /eJ/ } \\
\text { /ea/ }\end{array}$ & $\begin{array}{l}\text { leopard } \\
\text { measure }\end{array}$ & $\begin{array}{l}\text { /'lepəd/ } \\
\text { /'me3ə/ }\end{array}$ & $\begin{array}{l}\text { /leつ'рав/ } \\
/ \text { mеa'zув/ }\end{array}$ \\
\hline
\end{tabular}

The low front vowel /æ/ is systematically replaced by /a/ when it is represented by the letter A. Otherwise, it is pronounced as spelt, as the word "plait" as rendered in Table 22.

Table 22. Renderings of the vowel /ae/.

\begin{tabular}{|c|c|c|c|c|c|c|}
\hline & RP segment & FrancoE equivalent & Examples & RP rendering & Franc & endering \\
\hline Teachers and pupils & $/ \mathfrak{a} /$ & $\begin{array}{l}/ \mathrm{a} / \\
/ \varepsilon /\end{array}$ & $\begin{array}{l}\text { apple } \\
\text { plait }\end{array}$ & $\begin{array}{l}\text { /'æpl// } \\
\text { /plæt// }\end{array}$ & $\begin{array}{l}\text { /'apla/ } \\
\text { /plet/ }\end{array}$ & $\mathrm{N}=112(100 \%)$ \\
\hline
\end{tabular}

The low back vowel /a:/ is rendered as /a/ in all contexts except when the letter R occurs in the vicinity, as the words "after", "sergeant" and "car" in Table 23 show.

Table 23. Renderings of the /a:/.

\begin{tabular}{|c|c|c|c|c|c|c|}
\hline & RP segment & FrancoE equivalent & Examples & RP rendering & FrancoE & dering \\
\hline Teachers and pupils & /a:/ & $\begin{array}{l}\text { /а/ } \\
\text { /عв/ } \\
\text { /ав/ }\end{array}$ & $\begin{array}{l}\text { after } \\
\text { sergeant } \\
\text { car }\end{array}$ & $\begin{array}{l}\text { /'a:fta/ } \\
\text { /'sa:d3ənt// } \\
\text { /ka:/ }\end{array}$ & $\begin{array}{l}\text { /'aftes/ } \\
\text { /sєs'3ã/ } \\
\text { /kas/ }\end{array}$ & $\mathrm{N}=112(100 \%)$ \\
\hline
\end{tabular}

The vowel / $\mathrm{p} /$ is rendered as /a/ or /o/ depending on whether it is represented by a word containing the letter A like "what" or O like "hot" (Table 24).

Table 24. Renderings of the lvowel $/ p /$.

\begin{tabular}{|c|c|c|c|c|c|c|}
\hline & RP segment & FrancoE equivalent & Examples & RP rendering & Franco & lering \\
\hline \multirow{3}{*}{ Teachers and pupils } & \multirow{3}{*}{$/ \mathrm{p} /$} & $/ \mathrm{a} /$ & what & /wpt/ & /wat/ & \multirow{3}{*}{$\mathrm{N}=112(100 \%$} \\
\hline & & $10 /$ & because & /bi'knz/ & /bi'koz/ & \\
\hline & & /o/ & hot & $/ \mathrm{hpt} /$ & /ot/ & \\
\hline
\end{tabular}

Similarly, the vowel / $\mathrm{O}:$ / is rendered as /a/ when represented by the letter A as in the words "tall” and "awful”, as Table 25 shows.

Table 25. Renderings of the vowel /D:/.

\begin{tabular}{lllllll}
\hline & RP segment & FrancoE equivalent & Examples & RP rendering & FrancoE rendering \\
\hline \multirow{2}{*}{ Teachers and pupils } & $\mathrm{O} /$ & /a/ & tall & /t?:1/ & $/$ tal/ & $\mathrm{N}=112(100 \%)$ \\
\hline
\end{tabular}

The back vowel / / / is rendered / $\mathrm{OP} /$ in "look", /ul/ in "should" and /y/ in "sugar". As can be seen, the rendering varies depending on the spelling of the word in which it occurs, as Table 26 shows.

Table 26. Renderings of the vowel $/ \mho /$.

\begin{tabular}{|c|c|c|c|c|c|}
\hline & RP segment & FrancoE equivalent & Examples & RP rendering & FrancoE rendering \\
\hline Teachers and pupils & $/ v /$ & $\begin{array}{l}\mathrm{DO} / \\
/ \mathrm{ul} / \\
\mathrm{y} /\end{array}$ & $\begin{array}{l}\text { look } \\
\text { should } \\
\text { sugar }\end{array}$ & $\begin{array}{l}\text { llok/ } \\
\text { /fud/ } \\
\text { /'Juga/ }\end{array}$ & $\begin{array}{l}/ 1 \mathrm{OJk} / \\
/ \text { ful/ }\end{array}$ \\
\hline
\end{tabular}

The vowel /u:/ is hardly realized by these informants. It is systematically replaced by foreign sounds like /ui/ in "fruit", /DO/ in "pool" and /y/ in "blue", as shown in Table 27. 
Table 27. Renderings of the vowel /u:\%

\begin{tabular}{|c|c|c|c|c|c|c|}
\hline Teachers and pupils & RP segment & FrancoE equivalent & Examples & RP rendering & FrancoE rendering & \\
\hline & /u:/ & $\begin{array}{l}\text { /ui// } \\
\text { /OO/ } \\
\text { /y/ }\end{array}$ & $\begin{array}{l}\text { fruit } \\
\text { pool } \\
\text { blue }\end{array}$ & $\begin{array}{l}\text { /fru:t/ } \\
\text { /pu:// } \\
\text { /blu:/ }\end{array}$ & $\begin{array}{l}\text { /fьчi// } \\
\text { /pOว1/ } \\
\text { /bly/ }\end{array}$ & $\mathrm{N}=112(100 \%)$ \\
\hline
\end{tabular}

The back vowel $/ \Lambda /$ is pronounced $/ \mathrm{J} /$ when represented by the letter $\mathrm{O}$ as in "come" and /y/ when represented by the letter $\mathrm{U}$ as in "luck" (Table 28).

Table 28. Renderings of the vowel / $/$.

\begin{tabular}{|c|c|c|c|c|c|}
\hline & RP segment & FrancoE equivalent & Examples & RP rendering & FrancoE rendering \\
\hline Teachers and pupils & $/ \mathrm{A} /$ & $\begin{array}{l}1 \mathrm{D} / \\
/ \mathrm{y} /\end{array}$ & $\begin{array}{l}\text { come } \\
\text { lück }\end{array}$ & $\begin{array}{l}/ \mathrm{k} \Lambda \mathrm{m} / \\
/ \mathrm{l} \Lambda \mathrm{k} /\end{array}$ & $\begin{array}{l}/ \mathrm{kPm} / \\
/ \mathrm{lyk} /\end{array}$ \\
\hline
\end{tabular}

The mid-high central vowel /3:/ which is usually represented by a sequence of vowel followed by the letter R (V+R sequence) as in the words "prefer", "learn", is systematically replaced with the sequence V+/ь/, as the illustrations in Table 29 show.

Table 29. Renderings of the vowel $/ 3: \%$

\begin{tabular}{|c|c|c|c|c|c|}
\hline & RP segment & FrancoE equivalent & Examples & $R P$ rendering & FrancoE rendering \\
\hline Teachers and pupils & /3:/ & $\begin{array}{l}/ \varepsilon \mathrm{es} / \\
\text { /еав/ } \\
/ \mathrm{yb} / \\
/ \mathrm{is} /\end{array}$ & $\begin{array}{l}\text { prefer } \\
\text { learn } \\
\text { burn } \\
\text { dirt }\end{array}$ & $\begin{array}{l}\text { prr'f3:/ } \\
/ \text { lis:n/ } \\
\text { /b3:n/ } \\
\text { /ds:t/ }\end{array}$ & $\begin{array}{l}\text { /рье'fєь/ } \\
\text { /lеавn/ } \\
\text { /bysn/ } \\
\text { /dist/ }\end{array}$ \\
\hline
\end{tabular}

The mid-low central vowel /a/ is heard only when it functions as an epenthetic vowel. In other contexts, it is replaced by a variety of sounds suggested by the spelling of words, as Table 30 shows.

Table 30. Renderings of the vowel /a/.

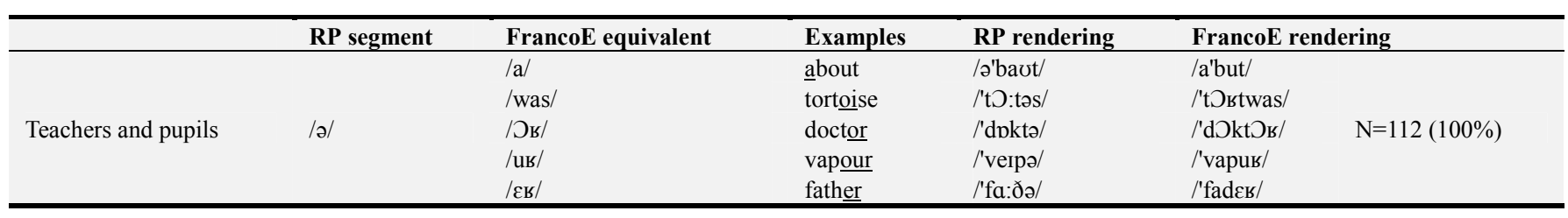

Diphthongs are considered next. All closing diphthongs are pronounced as the spellings of the words in which they occur suggest, as Tables 31 show. For example, /el/ is pronounced /a/ in "hate" and /e/ in "wait". /ai/ becomes /aji/ in "hi", /i/ in "cry" and /ui/ in "buy". / $\mathrm{OI} /$ is systematically pronounced / $\mathrm{Oji} /$ as in "boy" or /wa/ as in "voice". /əv/ may be monophthongised to /o/ as in "go" or /u/ as in "soul"; it may also be diphthongised as /oa/ as in "coat". Lastly, /av/ may be rendered in three ways: / $/$ as in "down", /awu/ as in "out" and /u/ as in "plough". These closing diphthongs are brought together in Table 31.

Table 31. Renditions of closing diphthongs.

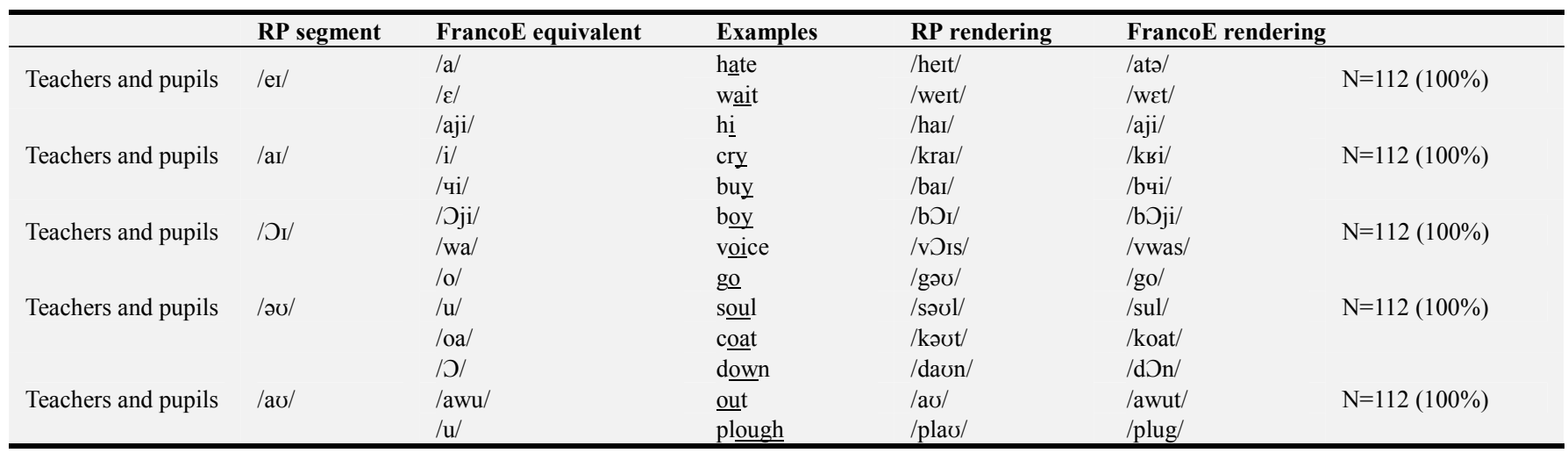

The same can be said of centring diphthongs, which are hardly realised as expected, as Table 32 indicates. To be specific,

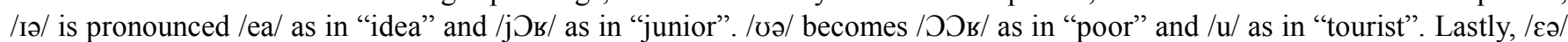
is rendered as /عь/ in "there" and "affair" and as /ав/ in "rare". 
Table 32. Renditions of centring diphthongs.

\begin{tabular}{|c|c|c|c|c|c|c|}
\hline & RP segment & FrancoE equivalent & Examples & RP rendering & FrancoE rendering & \\
\hline \multirow{2}{*}{ Teachers and pupils } & \multirow{2}{*}{ /Іа/ } & /ea/ & idea & /ar'dıə/ & /i'dea/ & \multirow{2}{*}{$\mathrm{N}=112(100 \%)$} \\
\hline & & /јОв/ & junior & /'d3oniə/ & /Зу'nјつь/ & \\
\hline \multirow{2}{*}{ Teachers and pupils } & \multirow[t]{2}{*}{ /৩ə/ } & /ООь/ & & /puə/ & /рつつь/ & \multirow{2}{*}{$\mathrm{N}=112(100 \%)$} \\
\hline & & $/ \mathrm{u} /$ & tourist & /'tuərIst/ & /tu'вist/ & \\
\hline \multirow{3}{*}{ Teachers and pupils } & \multirow{3}{*}{ /عə/ } & /عь/ & there & /ठعə/ & /dеь/ & \multirow{3}{*}{$\mathrm{N}=12(100 \%)$} \\
\hline & & /عь/ & affair & /ə'f $\varepsilon ə /$ & /a'fєь/ & \\
\hline & & /ав/ & rare & /reə/ & /ваь/ & \\
\hline
\end{tabular}

Regarding triphthongs, when the central element of a triphthong is the vowel $/ \mathrm{I} /$, this central element tends to be replaced by

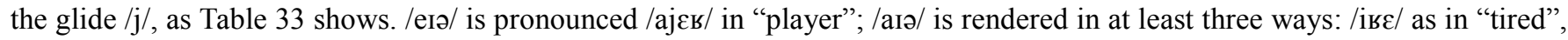
/ij/ as in "lion", and /ів/ as in "iron". Lastly, /әә/ is pronounced /ајєь/ as in "employer".

Table 33. Renditions of triphthongs containing $/ \mathrm{I} /$.

\begin{tabular}{|c|c|c|c|c|c|c|}
\hline \multirow[b]{2}{*}{ Teachers and pupils } & \multirow{2}{*}{$\begin{array}{l}\text { RP segment } \\
\text { /егə/ }\end{array}$} & \multirow{2}{*}{$\begin{array}{l}\text { FrancoE equivalent } \\
\text { /ајєь/ }\end{array}$} & \multirow{2}{*}{$\begin{array}{l}\text { Examples } \\
\text { player }\end{array}$} & \multirow{2}{*}{$\begin{array}{l}\text { RP rendering } \\
/ \text { pleı// }\end{array}$} & \multicolumn{2}{|c|}{ FrancoE rendering } \\
\hline & & & & & /'plejєь/ & $\mathrm{N}=112(100 \%)$ \\
\hline & & /ікع/ & tired & $/ \operatorname{taiəd} /$ & /tived/ & \\
\hline \multirow[t]{2}{*}{ Teachers and pupils } & /агә/ & /ij/ & lion & /laiən/ & /lijõ/ & $\mathrm{N}=112(100 \%)$ \\
\hline & & /ів/ & iron & /arən/ & /іво̃/ & \\
\hline Teachers and pupils & / Мга/ & /ајєь/ & employer & /Im'plつıә/ & /ãplwa'jes/ & $\mathrm{N}=112(100 \%)$ \\
\hline
\end{tabular}

When on the contrary this central element is the vowel / /, the glide /w/ is often used, as Table 34 shows. /əvə/ is systematically pronounced /оwes/ as in "slower" and /аvə/ becomes /аwиь/ or /ив/ as in "our".

Table 34. Renditions of triphthongs containing the glide $/ \mathrm{\%}$.

\begin{tabular}{|c|c|c|c|c|c|c|}
\hline & RP segment & FrancoE equivalent & Examples & RP rendering & FrancoE rendering & \\
\hline Teachers and pupils & /əขə/ & /oweь/ & slower & /sləvə/ & /sə'lowes/ & $\mathrm{N}=112(100 \%)$ \\
\hline Teachers and pupils & /avə/ & /аwus/ occasionally /us/ & our & /avə/ & /awus/ occasionally /us/ & $\mathrm{N}=112(100 \%)$ \\
\hline
\end{tabular}

Vowel + nasal sound sequences $(\mathrm{V}+\mathrm{N})$ are considered next. One interesting characteristic feature of the speech of these informants is its systematic use of nasal vowels. All instances of V+N, which surface as: /Im/ as in "simple", /In/ as in "interest", /عm/ as in "member", /عn/ as in "enter", /æm/ as in "ambition", /æn/ as in "ran", /a:m/ as in "example", /a:n/ as in "answer", /pm/ as in "composition", /pn/as in "continent", / $/ \mathrm{m} /$ as in "compass", and / $\mathrm{n}$ / as in "Monday" are replaced by the nearest French nasal sounds, as Table 35 shows.

Table 35. Renderings of the sequence " $V+N$ ".

\begin{tabular}{|c|c|c|c|c|c|c|}
\hline & RP segment & FrancoE equivalent & Examples & RP rendering & \multicolumn{2}{|c|}{ FrancoE rendering } \\
\hline Teachers and pupils & $/ \mathrm{Im} /$ & $\mid \tilde{\varepsilon} /$ & $\begin{array}{l}\text { impossible } \\
\text { simple }\end{array}$ & $\begin{array}{l}\text { /Im'ppsibl/ } \\
\text { /'simpl/ }\end{array}$ & 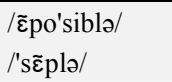 & $\mathrm{N}=112(100 \%)$ \\
\hline Teachers and pupils & /in/ & $\mid \tilde{\varepsilon} /$ & interesting & /'intrestin/ & 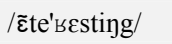 & $\mathrm{N}=112(100 \%)$ \\
\hline Teachers and pupils & $/ \varepsilon \mathrm{m} /$ & /ã/ & member & /'membə/ & /mãbeв/ & $\mathrm{N}=112(100 \%)$ \\
\hline Teachers and pupils & $/ \varepsilon \mathrm{n} /$ & /ã/ & enter & /'cntə/ & /'ãtєв/ & $\mathrm{N}=112(100 \%)$ \\
\hline Teachers and pupils & /æm/ & /ã/ & ambition & /æm'bIfn/ & /ãbi'sjõ/ & $\mathrm{N}=112(100 \%)$ \\
\hline Teachers and pupils & /æn/ & /ã/ & $\underline{\text { ran }}$ & /ræn/ & /ва̃/ & $\mathrm{N}=112(100 \%)$ \\
\hline Teachers and pupils & /a:m/ & /ã/ & example & /ıg'za:mpl/ & /عk'zãplə/ & $\mathrm{N}=112(100 \%)$ \\
\hline Teachers and pupils & /a:n/ & /ã/ & answer dance & /'a:nsə/ /da:ns/ & /'ãsweb/ /dãs/ & $\mathrm{N}=112(100 \%)$ \\
\hline Class Six teachers & $/ \mathrm{pm} /$ & $/ \tilde{\mathbf{\jmath}} /$ & composition & /kpmpə'zIJn/ & /kõpozi'sjõ/ & $\mathrm{N}=112(100 \%)$ \\
\hline Teachers and pupils & $/ \mathrm{pn} /$ & $/ \tilde{\mathbf{z}} /$ & continent & /'kpntınənt/ & /kõtinã/ & $\mathrm{N}=112(100 \%)$ \\
\hline Teachers and pupils & $/ \Lambda \mathrm{m} /$ & $/ \tilde{\mathbf{J}} /$ & compass & /'kımpəs/ & /'kõpas/ & $\mathrm{N}=112(100 \%)$ \\
\hline Teachers and pupils & $/ \Lambda \mathrm{n} /$ & $/ \tilde{\mathbf{z}} /$ & $\begin{array}{l}\text { Monday } \\
\text { month }\end{array}$ & $\begin{array}{l}\text { /'mındeI/ } \\
/ \operatorname{m} \wedge \mathrm{n} \theta /\end{array}$ & $\begin{array}{l}\text { /'mõde/ } \\
\text { /'mõt/ }\end{array}$ & $\mathrm{N}=112(100 \%)$ \\
\hline
\end{tabular}

The vowel system of the English of these informants may be said to include 17 segments: nine monophthongs, five diphthongs and three nasal vowels. These are outlined in Table 36. 
Table 36. The vowel system of the informants' English.

\begin{tabular}{|c|c|c|}
\hline Sounds & Examples & Transcriptions \\
\hline \multicolumn{3}{|c|}{ Monophthongs } \\
\hline /i/ & idea & idea \\
\hline /e/ & late & let \\
\hline$/ \mathrm{a} /$ & image & ima3 \\
\hline $\mid \varepsilon /$ & plait & plet \\
\hline$/ \mathrm{y} /$ & bussy & byzi \\
\hline /o/ & because & bikoz \\
\hline $\mathrm{D} /$ & come & $\mathrm{k} \bigcirc \mathrm{m}$ \\
\hline$/ \mathrm{u} /$ & soul & sul \\
\hline $\mid \mathrm{a} /$ & table & tablo \\
\hline \multicolumn{3}{|c|}{ Diphthongs } \\
\hline /ê/ & people & peOplə \\
\hline /iع/ & believe & belicv \\
\hline /ea/ & idea & idea \\
\hline 1DO/ & look & 1DOk \\
\hline /oa/ & coat & koat \\
\hline \multicolumn{3}{|c|}{ Nasal vowels } \\
\hline$|\tilde{\boldsymbol{\varepsilon}}|$ & simple & s̃̃plə \\
\hline$/ \tilde{\mathbf{a}} /$ & ran & ва̃ \\
\hline$/ \tilde{\mathrm{J}} /$ & uncle & ว̃klə \\
\hline
\end{tabular}

\section{Conclusion}

This study set out to check how much English is learnt at the phonological level by the time a Cameroonian child leaves primary school, English having been hurriedly made a compulsory subject in all primary schools in the country. The informants were primary school leaving pupils and their teachers, and the materials collected were tape-recordings of classroom lectures and the reading of a few samples of texts from the pupils' textbook. A number of questions were set to guide the study. The first two questions focused on the characteristic phonological features of the English of primary school teachers and of primary school leavers. It was found that the features of the English of these two sets of informants were similar and that these features differed from $\mathrm{RP}$ in every respect. Some distinctive RP consonants are elided like $/ \mathrm{h} /$ which is never pronounced, and the whole of the vowel system of their speech is different from RP. Consequently, their speech is unintelligible to any speaker of English.

The next question asked whether from the phonological features observed one could say that primary school leavers in Cameroon meet Government's expectations. These expectations were that the learners should be provided with the English that they will use at the end of their primary school education in their daily life requirements and when they go into secondary education. It is evident that these expectations are far from being attained. The last question enquired whether Government was serious about its official French-English bilingualism policy. In all likelihood, Government does not seem to be serious about its own policy as it uses unmotivated teachers who are not proficient in English to teach the subject. As was suggested in previous research (Kouega $[2,7]$ for example), there is a need to provide a certification for bilingual competence and the certificate issued has to be made to have market value in the country.

\section{References}

[1] MINEDUC (Ministère de l'Education: Ministry of Education). (2001). Programmes officiels de l'enseignementprimaire (Niveaux I, II et III) (Official syllabi for primary education (Levels I, II, and III)). Yaounde, Cameroon: Imprimerie Saint John.

[2] Kouega, J. P. (2003). English in Francophone elementary grades in Cameroon. Language and Education: An International Journal, 17 (6), 408-420.

[3] MINEDUC (Ministère de l'Education: Ministry of Education). (2000). Final report on the reinforcement of bilingualism in the Cameroon education system. Yaounde.

[4] Constable, D. (1977). Bilingualism in the United Republic of Cameroon. English Language Teaching Journal, 29 (3). 249-253.

[5] Tchoungui, G. (1983). Focus on official bilingualism in Cameroon: Its relationship to education. In Koenig, E. L., Chia E., and Povey J. (eds.). A sociolinguistic profile of urban centers in Cameroon. 93-116. Los Angeles: Cross Road Press.

[6] Kouega, J. P. (1999a). Forty years of official bilingualism in Cameroon. English Today, 15 (4), 38-43.

[7] Kouega, J. P. (2005). Promoting French-English individual bilingualism through education in Cameroon. Journal of Third World studies 22 (1), 185-196. On-line version: $\mathrm{http} / / /$ www.findarticles.com/p/articles/mi_qa3821/is_200504/ ai_n13642809.

[8] Kouega, J. P. (2007). The language situation in Cameroon. CILP (Current Issues in Language Planning), 1-94.

[9] Kouega, J. P. (2008). Bilingualism at tertiary level education in Cameroon: The case of the University of Yaounde II (Soa).http://www.isb6.org/static/proceedings/kouega.pdf, (1 September 2017).

[10] Biloa, E. (1999). Bilingual education at the University of Yaounde I: The teaching of French to English-speaking students. Official bilingualism and linguistic communication in Cameroon, 53-74. Peter Lang: New York.

[11] Echu, G. (1999). Le bilinguisme official au Cameroun: Critique et perspectives. In Echu, G. \& Grundstrom A. W., Eds., Official bilingualism and linguistic communication in Cameroon, 189-202. Peter Lang: New York.

[12] Simo Bobda, A. (2004). Tendances des recherches sur le bilinguisme (Français-Anglais) au Cameroun. Revue Internationale des Arts, Lettres et Sciences Sociales (RIALSS), $1(1), 39-57$.

[13] Ombouda Onana, E. (2008). The oral performance of Ewondo learners of English: A case study conducted in Lycee de Mefomo. Unpublished "Maitrise" dissertation, University of Yaounde I.

[14] Sokeng Piewo, S. C. (2011). The English language proficiency of Francophone secondary school leavers in Cameroon. Unpublished $\mathrm{PhD}$ Thesis, University of Yaounde I.

[15] Kouega, J. P. \& Sokeng Piewo, S. C. (2013). Performance of Francophone secondary school leavers in English structure and written expression English Linguistics Research, 2/1, 86106. On-line version: http://dx.doi.org/10.5430/elr.v2n1p86. 
[16] Abang, R. N. (2006). The teaching of English in francophone primary schools: A phonological perspective. Unpublished "Maîtrise" dissertation, University of Yaounde I.

[17] Simo Bobda, A. (1994). Aspects of Cameroon English phonology. Bern: Peter Lang.
[18] Kouega, J. P. (1999b). Some major speech traits of Cameroon media news in English. English Studies, 80 (6), 540-555. 